\title{
Subsidy Uncertainty and Microfinance Mission Drift
}

\section{B. Armendáriz, B. D'Espallier, M. Hudon and A. Szafarz}

This paper shines light on subsidy-dependent microfinance institutions (MFIs). Firstly, our model shows that subsidy uncertainty can have pervasive effects on MFIs' poverty-reduction mission. In particular, we argue that supply-driven uncertainty can lead to mission drift. MFIs maximize utility by serving the poor on the one hand, but must be financially sustainable on the other. Under the fear that subsidies can dry up, MFIs lend to wealthier clients in order to build precautionary savings. In a subsidy-uncertain world this is a rational reaction by MFIs struggling to preserve a pool of poor clients. We show that the incidence of mission drift increases with subsidy uncertainty. Secondly, we test the predictions of the model on original data collected from rating agencies assessment reports on 230 MFIs active in 60 countries over the period 19992006. Using both cross-section and panel-data regressions, we estimate the effect of subsidies on poverty reduction as proxied by average loan size, interest rates, and outreach. Our results suggest that more subsidies are associated with smaller loan sizes, but that higher subsidy uncertainty is positively correlated with higher interest rates. We also find that subsidy uncertainty is negatively correlated with outreach.

Keywords: microfinance, subsidies, mission drift, poverty reduction, average loan size, interest rate, outreach.

JEL Classifications: F35, G21, G28, 054, 057

\author{
CEB Working Paper $N^{\circ} 11 / 014$ \\ April 2011
}




\title{
Subsidy Uncertainty and Microfinance Mission Drift
}

\author{
Beatriz Armendáriz \\ Harvard University, University College London, and CERMi \\ Cambridge, MA 02138, United States
}

Bert D'Espallier

Hogeschool-Universiteit Brussel, and CERMi

1000 Brussels, Belgium

\section{Marek Hudon}

Université Libre de Bruxelles (ULB), SBS-EM, CEB, Burgundy School of Business, and CERMi

1050 Brussels, Belgium

\begin{abstract}
Ariane Szafarz*
Université Libre de Bruxelles (ULB), SBS-EM, CEB and CERMi

1050 Brussels, Belgium
\end{abstract}

April 2011

JEL Codes: F35, G21, G28, O54, O57

Keywords: microfinance, subsidies, mission drift, poverty reduction, average loan size, interest rate, outreach.

* Corresponding author:

Address: 50, Avenue F.D. Roosevelt, CP114/03, 1050 Brussels, Belgium

Email: aszafarz@ulb.ac.be, Tel: +32.(0)2.650.48.65. 


\begin{abstract}
This paper shines light on subsidy-dependent microfinance institutions (MFIs). Firstly, our model shows that subsidy uncertainty can have pervasive effects on MFIs' povertyreduction mission. In particular, we argue that supply-driven uncertainty can lead to mission drift. MFIs maximize utility by serving the poor on the one hand, but must be financially sustainable on the other. Under the fear that subsidies can dry up, MFIs lend to wealthier clients in order to build precautionary savings. In a subsidy-uncertain world this is a rational reaction by MFIs struggling to preserve a pool of poor clients. We show that the incidence of mission drift increases with subsidy uncertainty. Secondly, we test the predictions of the model on original data collected from rating agencies assessment reports on 230 MFIs active in 60 countries over the period 1999-2006. Using both cross-section and panel-data regressions, we estimate the effect of subsidies on poverty reduction as proxied by average loan size, interest rates, and outreach. Our results suggest that more subsidies are associated with smaller loan sizes, but that higher subsidy uncertainty is positively correlated with higher interest rates. We also find that subsidy uncertainty is negatively correlated with outreach.
\end{abstract}




\section{Introduction}

Poverty reduction via access to financial services has been heralded as the main mission of microfinance institutions (MFIs). ${ }^{1}$ This in turn is one of the most important reasons why a vast majority of MFIs have benefited (and continue to benefit) from millions of subsidies, often granted by donors - aid agencies, governments, and socially responsible investors. Subsidies are a contributing factor to the 150 million poor clients being served. ${ }^{2}$ Subsidies can however have a more powerful impact on poverty-reduction efforts. ${ }^{3}$ This paper argues that if the volume and timing of subsidies are designed in a less uncertain fashion by donors, subsidies will have a stronger impact on MFIs' poverty-reduction efforts. We construct an analytical framework to make our point, and deliver empirical evidence. We show that supply-driven subsidy uncertainty can have pervasive effects on MFIs' poverty-reduction mission.

\footnotetext{
${ }^{1}$ See, Armendáriz and Szafarz (forthcoming) for a summary on the top ten MFIs stated missions. The stylized facts suggest that most, particularly those MFIs which are located in the poorest regions of Asia, state that poverty reduction is their principal objective.

${ }^{2}$ Daley and Harris (2009).

${ }^{3}$ A typical case in point is small-sized loans demanded by women who account for 8 out of 10 loans extended by MFIs. Women account for as much as $70 \%$ of the world poorest (see, for example, the UNDP Human Development Report, 1996). However, Garikipati (2008) and Guérin et al., (2009) have challenged the impact of microfinance on women empowerment by exhibiting that lending to women may increase their intrahousehold financial vulnerability. Moreover, Agier and Szafarz (2010) argue that using gender as a proxy for poverty might reveal misleading since female borrowers can suffer from a glass-ceiling effect (being granted smaller loans than men, all other things being equal).
} 
Despite recent trends towards commercialization, the presence of non-governmental organization (NGOs) is very strong. This type of MFIs heavily depends on subsidies. Somewhat surprisingly, however, the literature linking subsidies in microfinance and poverty reduction is scarce. .Some notable exceptions include the work by Hudon (2010), Nawak (2010), and Hudon and Traca (forthcoming). Hudon (2010) finds that subsidies have little impact on the quality of MFIs' management, while Nawak (2010) and Hudon-Traca (forthcoming) find that subsidies can have a positive impact on financial efficiency, albeit marginally.

Ghosh and Van Tassel (2008) and Armendáriz and Szafarz (forthcoming) deliver theoretical models on mission drift, ${ }^{4}$ that is, a phenomenon where MFIs are tempted to serve wealthier clients at the expense of poorer clients. In practice, however, the divide between poor and wealthier clients, is proxied by average loan size. Pioneering work by Cull et al (2007) shows that commercialization involves MFIs extending loans that are larger on average, and moving away from serving women. The finding that women demand loans, which are smaller in size relative to those of their male counterparts, has prompted Mersland and Strøm (2010) to analyze mission drift via average loan size and the proportion of women served. Yet, the link between uncertainty regarding the supply of subsidies and mission drift has never been made. We argue that the crowding out of poor clients is rooted on subsidy uncertainty. Indeed, supply-driven uncertainty leads to the following trade-off: MFIs maximize utility by serving the poor on the one hand, but must lend to more profitable

\footnotetext{
${ }^{4}$ According to Ghosh and Van Tassel (2008) mission drift should be viewed as a dynamic phenomenon driven by profit-oriented donors. The one-period model proposed by Armendáriz and Szafarz (forthcoming) emphasizes the difference between mission drift and cross-subsidization.
} 
wealthier clients and build precautionary savings under the fear that subsidies can dry up on the other. Mission drift is thus be viewed as being created by donors', not because donors are profit oriented, as in Gosh-Van Tassel (2008), but because donors do not deliver subsidies under rules at best and the subsidies provided are uncertain at worse, be this in terms of quantity or timing.

Our theoretical results on the link between subsidy uncertainty and mission are supported by our empirical findings. The empirics exploit original data collected from rating agencies assessment reports on 230 MFIs active in 60 countries over the period 1999-2006.Using both cross-sectional and panel-data regressions, we estimate the potential effect of subsidies on poverty reduction as proxied by average loan size, interest rates, and outreach. Our results suggest that more subsidies are associated with smaller loan sizes, but that higher subsidy uncertainty is positively correlated with higher interest rates. We also find that subsidy uncertainty is negatively correlated with outreach.

The reminder of the paper is structured as follows. Section 2 reviews the literature on the role of subsidies in microfinance. Section 3 delivers an intertemporal theoretical model of subsidies and mission drift. Section 4 describes the data and presents the empirical results. Section 5 concludes. 


\section{The Role of Subsidies in Microfinance}

Historically, it is impossible to dissociate microfinance from subsidies. Microfinance emerged and developed in the mid-1970s thanks to visionary donor agencies such as the International Fund for Agricultural Development, the Deutche Gesellshaft für Technische Zusammenarbeit in Asia, and the United States Agency for International Development in Latin America. Probably one of the major recipients of foreign aid from multiple sources since has been the Grameen Bank, the flagship of microfinance in Asia. According to Morduch (1999)'s estimates, effective subsidies to the Grameen Bank were of about USD 175 million for the 1985-1996 alone. Similar stories on subsidization can be told about commercially-oriented microfinance institutions in Latin America, most notably about the emergence and rapid transformation of BancoSol in Bolivia, and of Banco Compartamos in Mexico.

Subsidies may help MFIs to reach their social mission and reach poor clients. A lively debate concerns the incentives to push MFIs towards their "double bottom line" of social and financial results (Conning, 1999; Copestake, 2007). Reaching a large number of very poor may justify subsidies (Zeller and Meyer, 2002). If MFIs are forced by competition to lower their costs and prices or increase their loan size, subsidies may therefore be a way to avoid mission drift. But, how can investors and donors be sure that subsidized MFIs will fulfill both goals? Some donors favour equity investments in shareholders firms when, for example, they aim at attracting new private investors (Mersland, 2009). Other forms of subsidized resources do not provide real control over the MFI's evolution, except if the donors put some conditionality on future disbursement. 
There is however a risk that subsidies to MFIs are used inefficiently, and that lax management practices result in limited outreach and high loan defaults (Bhutt and Tang, 2001). Excessive subsidization has in fact been disputed since the movement first gained momentum in the 1980s. The notion of "smart subsidies" tries to address these issues. It stresses that subsidies should be transparent, rule-bound and time-limited, with donors focusing on start-up expenses, institutional capacity building, product development, and foreseeing a clear exit strategy (Morduch, 2005).

Unlike subsidization and mission drift in Asia, the Latin American case is well documented (Armendáriz and Morduch, 2010). More recently, however, a new debate has emerged involving subsidies to microfinance institutions in Asia, most notably in India and Bangladesh $^{5}$. These debates suggest that ill-designed subsidies to microfinance are inherently pervasive. In what follows we show that there is nothing wrong with subsidizing microfinance as such, for as long as institutional donors do not generate uncertainty pertaining the amount and timing of foreign aid to the microfinance industry. While this is only part of the story, we feel strongly about moving the debate beyond mere anectotal evidence, first by laying down a model, and then by looking at what the data says through the lens of our framework.

Even if subsidies have been often debated in the microfinance sector, empirical evidence is scarce. Cull et al. (2007) show that village banking institutions receive most of the

\footnotetext{
${ }^{5}$ See The Economist, December $9^{\text {th }}, 2010$.
} 
advantages of subsidies, while individual lending institutions have the lowest fraction of subsidies in funding. NGOs tend to receive more subsidies, according to Cull et al. (2009). Hudon (2010) finds that subsidies have little impact on the quality of management. According to Hudon and Traça (forthcoming) subsidies have a positive impact on efficiency up to a certain threshold, above which the marginal effect becomes negative. Using data envelopment analysis, Nawaz (2010) confirms that subsidies contribute to the financial efficiency of MFIs, albeit marginally. Nevertheless, Caudill et al. (2009) find that lower total subsidies and lower subsidy per loan are associated with higher cost reduction over time. However, measuring the impact of subsidies is strongly limited by data availability. Moreover, the methodology adopted for computing subsidies differs across MFIs. Albeit these limitations, we will attempt to shed light on this issue through the lens of our model.

\section{The Model}

In what follows we present a stylized model of subsidies and mission drift. Consider an MFI serving two types of unbanked clients or, equivalently, offering two types of loans, 1 and 2, respectively. Loan 1 is available to the poor, its size at time $t, s_{1}(t) \geq 0$, is chosen by the MFI. ${ }^{6}$ Loan 2 is available to wealthier yet unbanked clients who require a minimal size

\footnotetext{
${ }^{6}$ Implicit in this assumption is that the MFI has all the bargaining power. This might be true for several large MFIs that enjoy monopoly power. An alternative justification for this assumption is that the size of the loan offered by the MFI is incentive compatible.
} 
$\left(\forall t: s_{2}(t)>\underline{s}\right)$ to start an investment project. This project can only be financed by the MFI. ${ }^{7}$ The interest rate charged is exogenously fixed to $\rho$.

In period $t>0$, the MFI receives a stochastic subsidy $K_{t} \geq 0$, and provides $N_{1}(t)$ loans of type 1 and $N_{2}(t)$ loans of type 2 . It faces transaction costs $f\left(N_{1}(t), N_{2}(t)\right)$ depending on the number of both types of loans. This function is assumed linear. Relative to wealthier clients, we assume that the poor are more costly to serve:

$f\left(N_{1}, N_{2}\right)=\gamma_{1} N_{1}+\gamma_{2} N_{2}, \quad \gamma_{1} \geq \gamma_{2}>0$

The MFI's principal objective is to maximize outreach via microloans. That is, the MFI maximizes expected utility, which is a function of the MFI's outreach objective, that is, to extend the largest number of loans to poor clients. The MFI controls the size of each type of loans, $s_{1}(t)$ and $s_{2}(t)$, subject to the budget constraint. Regarding dynamics, future utility is discounted by factor $\beta \leq 1$. The utility function is assumed additive, and future utility is discounted with an exponential factor:

$U\left[N_{1}(1), \ldots, N_{1}(t), \ldots\right]=\sum_{t=1}^{\infty} \beta^{t} U\left[N_{1}(t)\right]$

where $U[$.$] is an increasing concave function.$

\footnotetext{
${ }^{7}$ Implicit in this assumption is that there is only one MFI serving all clients in the loan market. Our results will not be altered if we were to assume that the MFI is perfectly competitive, and, as long as the loan contract is incentive compatible, both types of clients will face the exact same loan contract from all MFIs operating in the market.
} 
In particular, we are assuming that the subsidy received by the MFI, $K_{t}$, is the only stochastic variable in the model. The dynamics of the decision-making process is:

- At time 1, the MFI receives subsidy $K_{1}$, and allocates this subsidy as follows: it extends loans partly to poor clients $\left(N_{1}(1)\right.$ loans) and partly to wealthier clients ( $N_{2}(1)$ loans). The MFI maximizes expected utility, which delivers an optimal outreach level $N_{1}(1)$.

- At the end of period 1, all loans are reimbursed delivering a return, $\rho>0$.

- At time 2 and beyond, resources available to the MFI are made of a new subsidy (e.g., $K_{2}$ ) and the net profit of its lending activity. These resources arise from lending activity between the MFI and poor clients (e.g., $N_{1}(2)$ loans) and partly from lending activity with wealthier clients (e.g., $N_{2}(2)$ loans) through expected utility maximization.

The resulting model is:

$$
\begin{aligned}
& \quad \underset{s_{1}(t), s_{2}(t), N_{1}(t), N_{2}(t)}{\operatorname{Max}} E \sum_{t=1}^{\infty} \beta^{t} U\left[N_{1}(t)\right] \\
& \text { s.t. } K_{1}=s_{1} N_{1}(1)+s_{2} N_{2}(1)+\gamma_{1} N_{1}(1)+\gamma_{2} N_{2}(1) \\
& \qquad K_{t+1}+(1+\rho)\left[s_{1} N_{1}(t)+s_{2} N_{2}(t)\right]=s_{1} N_{1}(t+1)+s_{2} N_{2}(t+1)+\gamma_{1} N_{1}(t+1)+\gamma_{2} N_{2}(t+1), t>0 \\
& \quad s_{1}(t) \geq 0 ; s_{2}(t) \geq \underline{s},
\end{aligned}
$$


Hypothesis 1: Lending to the poor is $\operatorname{costly}^{8}\left(\gamma_{1}>1+\rho\right)$ and lending to the wealthier is $\operatorname{profitable}^{9}\left(\gamma_{2}<1+\rho\right)$

It follows that, given that outreach is to be maximized, the MFI will always offer the smallest possible loans to the poor: $\forall t: s_{1}^{*}(t)=0$. Let us denote by $C_{t}$ the cost of serving $N_{1}(t)$ poorer clients at time $t$ :

$$
C_{t}=\gamma_{1} N_{1}(t)
$$

and let us define accordingly:

$U\left[N_{1}(t)\right]=V\left[C_{t}\right]$

The function $V[\square]$ benefits from the same properties than $U[\square]$. Namely, $V[\square]$ is increasing and concave, with: $V^{\prime}\left[C_{t}\right]=\gamma_{1} \cdot U^{\prime}\left[\gamma_{1} N_{t}(t)\right]$.

\section{Hypothesis 2: The type 2 loans have a fixed (normalized) size:}

$$
\forall t: s_{2}(t)=\underline{s}=1
$$

\footnotetext{
${ }^{8}$ Otherwise stated, lending to the poor is similar to extending grants, thereby making the microfinance industry look like an aid agency rather than a lending institution. However, reimbursements by the poor make the lending activity less costly than giving grants, provided transactions costs are not too high.

9 If lending to the wealthier were not profitable, the MFI would never choose to issue loans of type 2 as the corresponding clients do not participate to the outreach to be maximized.
} 
Hypothesis 2 is a technical assumption, which is required as the specification of the cost function would otherwise push $s_{2}(t)$ to be artificially large (the variable cost is expressed per loan independently of its size).

Loans of type 2 appear as a profitable side-business that does not contribute to the MFI mission directly, but offers additional capital for reaching the poor. The rate of return of this business is constant. Indeed by lending one dollar at the cost of $\gamma_{2}$ to a wealthier client the MFI generates $(1+\rho)$ dollars. As, by hypothesis $1, \gamma_{2}<1+\rho$, the positive rate of return of this activity is defined by:

$\frac{1+\rho}{\gamma_{2}}=1+r \Leftrightarrow r=\frac{1+\rho-\gamma_{2}}{\gamma_{2}}>0$

Importantly, rate $r$ is used by the MFI for investing, not for borrowing.

With these conventions, model (3) rewrites:

$$
\underset{C_{t}}{\operatorname{Max}} E \sum_{t=1}^{\infty} \beta^{t} V\left[C_{t}\right]
$$

s.t. $W_{t+1}=\left(W_{t}-C_{t}\right)(1+r)+K_{t+1}, t>1$

$$
\begin{aligned}
& C_{t} \geq 0, t>0 \\
& W_{t}-C_{t} \geq 0, t>0
\end{aligned}
$$

where $W_{t}$ represents the financial assets of the MFI at $t$ after subsidy and before lending to any borrower. ${ }^{10}$

\footnotetext{
${ }^{10}$ Under this specification, our model is formally similar to an intertemporal consumption model $a$ la Hall (1988). Indeed, the funds devoted to serving the poorer are those that bring utility while the funds lent to the wealthier correspond to savings that help serving the poorer in the future. The parallel between our model and the intertemporal consumption model is not just formal as it relates quite strongly to the problem faced by
} 
Our stylized model suggests that a typical MFI can finance its outreach maximization objective in two ways: (1) it obtains external subsidies, and (2) it launches a profitable side business. The latter could in principle involve any kind of profitable activity. We however believe that it is natural to suppose that the MFI's side business is financial, because of economies of scale considerations, for example. Specifically, extending loans of a larger size to wealthier clients can be the profitable business to generate income by MFIs. Because lending to the unbanked wealthier clients involves a transaction cost, $\gamma_{2}$, the charged interest rate $\rho$ is not a rate of return. The actual rate of return, which takes into account transaction costs, is:

$r=\frac{1+\rho-\gamma_{2}}{\gamma_{2}}$.

This rate is positive for as long as lending to wealthier clients is profitable.

In most consumption models, the same interest rate is applicable to saving and borrowing. We however focus on the lending side, and therefore exclude borrowing as a side activity. This is captured by the constraint: $N_{2}(t) \geq 0$. In particular, including a liquidity constraint avoids the risk of bankruptcy which remains unclear when dealing with welfare-oriented NGOs.

charitable institutions, MFIs included. In particular, our main point here is that like consumption, lending to the poor is a costly operation which needs to be financed. 
In order to discuss the outcome of the model in a progressive way, we will first present the results when the liquidity constraints are ignored. While we do this for the sake of clarity, we are aware of the fact that excluding liquidity constraints from the analysis is unrealistic. We therefore introduce them in a follow-up subsection.

\subsection{The Model without Liquidity Constraints}

Let us first consider model (8) under the assumption that borrowing allowed. This means that the MFI charges wealthier clients with a market net interest rate, $r$, which is also available for borrowing. The model is then:

$\underset{C_{t}}{\operatorname{Max}} E \sum_{t=1}^{\infty} \beta^{t} V\left[C_{t}\right]$

s.t. $W_{t+1}=\left(W_{t}-C_{t}\right)(1+r)+K_{t+1}, t>1$

Following Hall (1988), the Euler equation for this model is:

$E_{t} V^{\prime}\left(C_{t+1}\right)=\frac{1}{\beta(1+r)} V^{\prime}\left(C_{t}\right)$

At first sight, the subsidies seem to have disappeared from the dynamics in (11). Actually, they are still there, but indirectly through the expectation mechanism. However, it turns out to be impossible to derive the optimal loan allocation analytically without strong additional conditions on the dynamics of the subsidies. ${ }^{11}$ Most models of this kind assume a random

\footnotetext{
11 see Zeldes (1989).
} 
walk, which means that the subsidy at time $t$ is equal to the previous subsidy plus a white noise. Then, the mean subsidy is a constant and its variance is growing over time.

In this case, and under fairly general assumptions on the utility function in (8), Appendix 1 proves that when the MFI faces future uncertain subsidies, it tends to lower its outreach and make precautionary savings via lending to wealthier clients in order to be able to maintain future outreach at an acceptable level, that is, a level which is in line with its outreach objective. By lowering the number of loans it extends to the poor, the MFI might seem as if it had drifted from its mission, when in fact it is actually adopting a cautious behavior while at the same time preserving the conditions for the perpetuation of its mission in the future. ${ }^{12}$

\subsection{The Model with Liquidity Constraints}

The precautionary savings approach taken up so far might be misleading, however. If all MFIs had deviated from their mission, donors would have withdrawn their support. Yet, this has not happened in reality. Moreover, donors such as the Inter-American Development Bank have helped NGOs to transform themselves into fully commercial MFIs as in the case of Bolivia's BancoSol. Why?

\footnotetext{
12 As pointed out by Caballero (1991), the impact of precautionary savings may be huge. According to his estimation on US data, uncertainty on income can induce more than 60 percent of wealth devoted to precautionary savings. While the problem at stake here is different, this number needs not to be taken at face value and specific estimations would be required to assess the impact of precautionary savings in the specific case of MFIs. For instance, one may conjecture that MFIs are less concerned with their future activity than individuals are with their future consumption. Nevertheless, caution is a basic principle in firm management and MFIs' managers not only care about the future of their institution, but also about their own career concerns.
} 
A key point in our analysis so far is that MFIs do not face liquidity constraints, which is clearly not the case for a vast majority of MFIs. ${ }^{13}$ By introducing liquidity constraints, which are binding, outreach reduction will be reinforced. In other words, when the unconstrained optimal outreach is not reachable anymore due to the impossibility of borrowing to attain its objective, the MFI is going to be locked in a lower outreach level.

More formally, consider model (8) including the liquidity constraint. The MFI is therefore bound to allocate its available resources only. Following Zeldes (1989), the Euler equation becomes:

$E_{t} V^{\prime}\left(C_{t+1}\right)=\frac{1}{\beta(1+r)} V^{\prime}\left(C_{t}\right)+\lambda_{t}$

where $\lambda_{t}$ is the Lagrange multiplier associated to the non-negativity constraint: $W_{t}-C_{t} \geq 0$. Since the MFI is constrained from borrowing but not from saving, one has: $\lambda_{t} \geq 0$. If, at time $t$, this constraint is not binding, then $\lambda_{t}=0$ and the results from the previous section applies. However, when this constraint is binding $\lambda_{t}>0$, the current outreach is lower and the future expected outreach is higher than in the previous case. Under this scenario, the no-borrowing constraint makes it impossible to use future expected subsidies "to smooth" current outreach.

\footnotetext{
${ }^{13}$ In practice, the situation is less clear-cut as subsidies to MFIs are sometimes provided under the form of cheap long-term credit.
} 
Schechtman (1976) shows that, under fairly general conditions on stochastic subsidy (but zero interest rate and no discounting factor), the optimal outreach under the no-borrowing constraint is smaller at any time to the one prevailing without such constraint. In the same vein, Zeldes (1989) states that precautionary savings due to the uncertainty on future subsidies are larger with liquidity constraint.

Indeed, an MFI that expects to be running out of cash at some point in the future will reduce its current outreach and serve wealthier clients in order to save for the future. This will make it deviate from its certainty-equivalent optimal outreach (Zeldes, 1989). Observing such deviations might in turn be misinterpreted as an ex post sign of mission drift. Even if the observed MFI never hits the liquidity constraint, this may actually be attributable to its $e x$ ante rational optimization behavior in the presence of risk aversion.

\section{Empirical Results}

\subsection{Data Description and Estimation Method}

Our empirical analysis consists of analyzing the association between subsidy uncertainty and mission drift-variables for a worldwide sample of 230 MFIs active in 60 countries over the period 1999-2006. ${ }^{14}$ Data were gathered from assessment reports made up by external

\footnotetext{
${ }^{14}$ Appendix 2 provides information about the geographical composition of the sample by listing the number of MFIs and different types in each country.
} 
rating agencies. The main benefit of rating-data is that rating reports have been compiled by a third party and therefore less likely to be biased or 'upgraded' by the MFIs, for instance to secure future donor funds. For most MFIs (53.3\%) we have 3 years of data available, although it can also be 2 years $(27.9 \%), 4$ years $(14.4 \%)$ or 5 years of data $(0.4 \%)$. The dataset contains a wide variety of different MFI types with 114 NGOs (49.5\%), 53 non-bank financial institutions (23.04\%), 46 cooperatives (20\%) and 17 for-profit institutions $(0.7 \%)$.

The MFIs in our sample are amongst the largest and best-managed institutions in the world and, given the well-established concentration of microfinance clients (Honohan, 2004), our sample should be representative of the universe of microfinance activities. In fact, basic statistics obtained from our sample appear to be similar to those coming out of the largest existing database in microfinance. For instance the 890 MFIs in the 17th MicroBanking Bulletin [MBB] (MicroBanking Bulletin, 2008) yield an average Operational Sustainability of $115 \%$ compared to ours of $117 \%$. The average number of borrowers is 11,041 for the MBB compared to 10,232 in our database; the average nominal yield of is $30 \%$ in the MBB and $31 \%$ in our database and, finally, the average staff productivity is 112 in the MBB while it is 132 borrowers per staff in our database.

Table 1 reports summary statistics for the sample under study. The median MFI is 7 years in operation and serves around 4,700 credit clients with a staff of 44 members. The total outstanding loan portfolio for the median MFI is 1,754 thousands US dollars, and the average loan granted is 398 dollars. The MFIs in the sample depend heavily on subsidies as 
can be seen from the ratio donated equity scaled by total equity which indicates that donated equity is roughly half the amount of total equity for the median MFI.

\section{< Insert Table 1 here >}

Subsidy uncertainty is defined as the standard deviation of the share of equity that is donated. This variable, which has a mean of 0.19 and ranges between 0 and 3.51, grasps the dispersion in subsidies each MFI has faced over the years. The closer to zero, the less subsidies have fluctuated; the larger the number, the more subsidies have fluctuated over the observed sample period.

Measuring 'mission drift' is more challenging because a move from costly very poor clients towards profitable wealthier clients can be reflected in the MFI's numbers in several ways. First, mission drift is expressed as the depth of outreach in terms of the number of poor borrowers served. Our theoretical model differentiates between profitable loans that generate interests (with normalized size 1) and non-profitable loans that generate zero interests (with normalized size close to 0 ), and predicts that subsidy uncertainty drives a reduction in the number of costly loans. However, since the database includes the total number of loans, but not split into profitable and costly loans, we take the percentage change in number of active borrowers as a proxy for the variation in non-profitable loans. This variable has a mean of 0.19 and ranges between -0.81 and 0.90 , suggesting that, on average, the clients-base is growing with $20 \%$ each year, whereas in $15 \%$ of the cases there is a reduction in clients-base. In section 4.2 we analyze the relation between subsidy uncertainty and changes in active borrowers. The intuition is that higher subsidy uncertainty 
is associated with smaller, or even negative, changes in active borrowers, suggesting a move towards wealthier clients when faced with higher subsidy uncertainty.

Mission drift could also lead to higher average loan sizes suggesting that MFIs are moving away from costly small loans towards larger loans that are usually less costly. As Cull et al. (2009) argue MFIs can increase their profit margin significantly by cutting back on transaction costs related to small loans. We scale average loans by per capita GNI to allow cross-country comparisons.

Lastly, mission drift could translate into higher interest rates charged on new or renegotiated loans. In that sense, a higher average annual interest rate charged on its loans could reflect an MFI's move towards wealthier unbanked clients. In section 4.3 we analyze the relation between subsidy uncertainty on the one hand, and average loans and interest rates charged on the other hand. We control for the dependence between average loans and interests by analyzing both variables simultaneously.

\subsection{Subsidy Uncertainty and Outreach Variation}

Table 2 summarizes the results from regressing the change in the number of active borrowers on subsidy uncertainty and a set of controls, using pooled Ordinary-LeastSquares (OLS) as well as Random-Effects (RE). The hypothesis to be tested for is that higher subsidy uncertainty is associated with smaller growth in active borrowers. Indeed, the theoretical model predicts that the number of non-profitable clients declines when the MFI faces more subsidy uncertainty. The columns of table 2 correspond to different estimation 
methods and the subsequent inclusion of time and regional dummies. Standard errors are corrected for heteroskedasticity and autocorrelation and are clustered at the MFI-level.

For the control variables we use variables that are typically used in related performancestudies: MFI-type, age, size, a dummy indicating whether the MFI offers savings in addition to credit, portfolio-at-risk indicating the proportion of the loan-portfolio that is being repaid late. We add the level of subsidies scaled by equity as an extra control to isolate the effect of variation in subsidy uncertainty from the actual subsidization rate.

< Insert Table 2 here >

Table 2 indicates that more subsidy uncertainty significantly drives smaller increases in active borrowers, all other things equal. This result holds for pooled OLS (columns 1-3), and RE (columns 4-6) estimations, and regardless of the inclusion of time and/or regional dummies. Furthermore, the F-statistics (for OLS) and Wald $\chi^{2}$-statistics (for RE) denote joint significance of the overall model in all cases. This suggests that MFIs facing higher uncertainty with respect to subsidies have slower growth in outreach, in line with the theoretical prediction. As far as the controls are concerned, a higher growth in clients-base is obtained for for-profit institutions and younger MFIs.

In Table 3, we study the relation between subsidy uncertainty and having a positive-versusnegative growth in clients. In our data, growth in clients is negative in $15 \%$ of the observations (each observation concerns one MFI and one year). Using Logit and Probit regressions, we investigate whether subsidy uncertainty is a significant predictor for the 
probability for an MFI to experience a positive outreach growth. The columns represent different estimation methods, and inclusion of time and regional dummies. Standard errors are corrected for autocorrelation and heteroskedasticity.

< Insert Table 3 here >

Table 3 shows that higher subsidy uncertainty significantly reduces the chance of having positive changes in credit clients. Put differently, MFIs with uncertain subsidies more often have negative changes in their credit clients. These results are in line with the theoretical prediction that non-profitable loans are reduced when MFIs face uncertainty with respect to subsidies.

\subsection{Subsidy Uncertainty, Average Loan Size, and Interest Rates}

Both average loans and interest rates are used in the literature to measure mission drift. However, the interest rate charged on a loan is intrinsically linked with the average loan size and consequently both variables are jointly determined within the MFI. In our data the overall sample-correlation between portfolio yield and average loans is -0.10 suggesting smaller loans are more costly than larger loans. Therefore, rather than analyzing the relation between subsidy uncertainty and average loan size on the one hand, and subsidy uncertainty and interest rate on the other, we estimate a system of equations where we regress both variables simultaneously on subsidy uncertainty and a number of controls. The main benefit of this approach is to take into account the endogeneity of average loan size and interest rate by allowing the errors of the different equations to be correlated. 
Specifically we estimate the following set of equations:

$\left\{\begin{array}{c}\text { interest rate }_{i, t}=\beta_{0}+\beta_{1} \text { subsidy uncertainty }{ }_{i}+\beta^{\prime} \text { controls }+\varphi_{i, t} \\ \text { average loan size }_{i, t}=\gamma_{0}+\gamma_{1} \text { subsidy uncertainty }_{i}+\gamma^{\prime} \text { controls }+\omega_{i, t}\end{array}\right.$

where parameters $\beta_{0}, \beta_{1}$, and $\beta^{\prime}$ are estimated simultaneously with $\gamma_{0}, \gamma_{1}$, and $\gamma^{\prime}$, and correlation between $\varphi_{i, t}$ and $\omega_{i, t}$ is allowed for so that endogeneity is taken into account.

The parameters in (16) are estimated using the seemingly-unrelated-regression (SUR) procedure developed in Zellner (1962), Zellner and Huang (1962) and Zellner (1963) and available in most statistical packages.

Table 4 summarizes the results. The different columns show what happens if time dummies and regional dummies are added subsequently. Interestingly, the Breusch-Pagan test statistic for independence is always highly significant at the 5\% significance level, hence rejecting the null-hypothesis that both regressions in the system are uncorrelated. In other words, interest rate and average loan size are indeed simultaneously determined and therefore modeling them jointly rather than in isolation is a desirable approach.

< Insert Table 4 here >

The impact of subsidy uncertainty is positive and significant in all interest-rate regressions, and insignificant in all average-loan-size regressions. This suggests that higher subsidy uncertainty is associated with higher interest rates, but do not affect average loan size. The insensitivity of average loan size to subsidy uncertainty might seem striking at first sight. 
However, albeit its frequent use in empirical studies, average loan size is a rather weak indicator of "mission fulfillment" (Dunford, 2002; Armendariz and Szafarz, forthcoming).

An advantage of estimating a system is that joint F-tests can be performed across specifications. We report a joint F-test for the null that both coefficients for subsidy uncertainty are jointly insignificant. In all specifications this tests rejects the null suggesting that there is indeed a positive significant relation between the mission drift variables and subsidy uncertainty.

With respect to the control variables a number of interesting results emerge. First, more subsidies is significantly associated with smaller loans confirming that MFIs that depend more on donated funds usually offer smaller loans and charge lower interest rates. Secondly, MFIs that offer savings in addition to credit usually provide larger loans in line with the idea that voluntary savings are not being offered by MFIs focusing on the very poor. Next, NGOs offer smaller loans, but there is no relation between MFI-type and the interest rate charged. Finally, larger MFIs as measured by the (natural logarithm) of equity offer larger loans and have lower interest rates.

\subsection{Robustness Checks}

A number of checks are performed to test whether the observed relations remain robust after some modifications of the data and changing of set-up. Results are presented in Table 5. In Panel A we use the spread of donated equity scaled by total equity as a measure for subsidy uncertainty instead of the standard deviation. This is to ensure that the previous results are 
not driven by the definition of the subsidy uncertainty-measure. After all, the standard deviation of subsidies for each MFI is calculated based upon a very limited number of observations per MFI, and the results might be influenced by construction of this measure. The spread of donated equity simply calculates the difference between the maximum value and the minimum value for donated equity scaled by total equity, and therefore is less subject to problems related to construction of the standard deviation. In Panel B we reestimate the system of equations when only those MFIs are taken up for which we have three years of data. This check is given in by a similar concern on the definition of subsidy uncertainty by means of the standard deviation. Although the standard deviation takes into account the number of observations for each MFI by dividing by this number in its denominator, it could still be the case that more observations per MFI result in larger dispersion. Finally, in Panel $\mathrm{C}$ we adjust donated equity for donations in cash, in-kind subsidies and revenues from donations and use this adjusted subsidy-measure instead of donated equity to calculate the standard deviation.

$<$ Insert Table 5 here >

As can be seen from Table 5, these modifications do not change the general results obtained in previous tables. Again, there is a highly significant positive relation between subsidy uncertainty and the interest rate and a positive insignificant relation between subsidy uncertainty and average loan size. Moreover, the Breusch-Pagan test rejects the null that the equations of the system are unrelated and the joint F-test indicates that the relation between mission drift and subsidy uncertainty is significant in the system. With respect to the 
control-variables we also observe very similar results. Having more subsidies is associated with smaller average loans and offering voluntary savings is associated with larger average loans. Additionally, having an NGO-status is associated with smaller average loans.

\section{Concluding Remarks}

Historically, the dual objective of microfinance institutions has been that of reducing poverty and attaining self-sufficiency. Donors continue subsidizing microfinance, and rigorous studies on the effects of microfinance on poverty reduction are context-specific at best, fail to show significant impact at worse.

This paper suggests that the main reason why a vast majority of MFIs have failed to meet their dual objective can be found in the supply of subsidies. If these were better designed, under clear rules, and, more importantly, less uncertain, MFIs can potentially meet their dual objective more easily, and the risk of MFIs drifting from their poverty-reduction mission would be minimized. To make our point, we have constructed in this paper an intertemporal model showing that socially oriented MFIs facing subsidy uncertainty may well drift away from its mission for motives pertaining to precautionary savings.

Our empirical analysis, albeit the data limitations, lends support to our theoretical analysis: subsidy uncertainty is associated with MFIs having lower growth of poor clients (or outreach) and with higher interest rates. The association between subsidy uncertainty and loan size is not as strong. It is important to mention the severe data limitations for future research, and, hopefully, for more transparency and dissemination of data by aid agencies: 
Firstly, data limitations made it impossible to test the exact model prediction. Indeed, we solely observe the total number of borrowers and therefore use the decrease in borrowers as a proxy for mission drift, relying on the implicit assumptions that costly borrowers are more numerous than profitable ones, all things equal. Future research could be directed to identifying profitable versus costly loans and isolating the impact of subsidy uncertainty on costly loans.

Secondly, subsidy uncertainty may be represented by several indicators, ${ }^{15}$ and preliminary checks indicate that the impact of subsidy uncertainty depends on the measure used. Moreover, measuring standard deviations with a few observations (five, at best) is hazardous. It makes our empirical results possibly distant from their theoretical reference based on steady-state considerations. Regarding long-term implications, the data are simply incapable of providing insights given the lack of time perspective. Only the theory helps comparing long-term impacts of different subsidization schemes. For all these reasons, future research could be aimed at defining subsidy uncertainty over a longer time-frame, and using other additional information to measure uncertainty the MFI faces with respect to its subsidy-income stream. Lastly, our model assumes that randomness solely stems from subsidy delivery and neglects all other sources of uncertainty faced by MFIs (defaults from borrowers, macro-economic conditions, political risks, to name as few). A more realistic model should take into account these sources of uncertainty as well.

\footnotetext{
${ }^{15}$ Not only do several statistical parameters exist, but also the way variables are scaled may affect the results.
} 
Despite these limitations, our results give food for thought for donors who need to design efficient subsidy schemes in a long-term perspective. Basically, our model states that donors truly motivated by poverty alleviation should adopt a stable subsidization policy and follow clear-cut rules. In that way, they will efficiently help MFIs fulfilling their mission. All other things equal, uncertainty might be positively correlated with mission drift because legitimate self-sustainability motives push MFIs to favor profitable clientele segments.

\section{References}

Abrams, J. and D. von Stauffenberg (2007), "Are public development institutions crowding out private investment in microfinance?," Working Paper, MicroRate.

Agier, I. and A. Szafarz (2010) "Microfinance and gender: Is there a glass ceiling in loan size?,", CEB-Working Paper N 10/047, ULB, Brussels.

Armendariz B. and J. Morduch (2010), The Economics of Microfinance (2 ${ }^{\text {nd }}$ Edition), Cambridge, MA: MIT Press.

Armendariz, B. and A. Szafarz (forthcoming), "On mission drift in microfinance institutions", in B. Armendariz and M. Labie (Eds), The Handbook of Microfinance, London-Singapore: World Scientific Publishing.

Bhutt, N. and S.-Y. Tang (2001), "Delivering Microfinance in Developing Countries: Controversies and Policy Perspectives," Policy Studies Journal, 29, 2, 319-333.

Broze, L., C. Gouriéroux, and A. Szafarz (1985), "Solutions of Dynamic Linear Rational Expectations Models," Econometric Theory, 1, 341-368.

Caballero, R.J. (1991), "On the sign of the investment-uncertainty relationship," American Economic Review, 81, 1, 279-288.

Cassar, A., L. Crowley, and B. Wydick (2007), "The effect of social capital on group loan repayment: evidence from field experiments," Economic Journal, 117, F85-F106.

Caudill, S., D. Gropper, and V. Hartarska (2009), "Which microfinance institutions are becoming more cost-effective with time? Evidence from a mixture model," Journal of Money, Credit, and Banking, 41, 4, 651-672. 
Conning, J. (1999), "Outreach, sustainability and leverage in monitored and peer-monitored lending," Journal of Development Economics, 60, 51-77.

Copestake, J. (2007), "Mainstreaming microfinance: Social performance management or mission drift?," World Development, 35, 10, 1721-1738.

Cull, R., A. Demirgüç-Kunt, and J. Morduch (2007), "Financial performance and outreach: a global analysis of leading microbanks," Economic Journal, 117, 517, 107-133.

Cull, R., A. Demirguc-Kunt, and J. Morduch (2009) "Microfinance meets the market," Journal of Economic Perspectives, 23, 1, 167-192.

Daley and Harris, S. (2009), State of the Microcredit Summit Campaign Report, Results, Washington D.C,

Dunford, C. (2002), "What's wrong with loan size?," Freedom from Hunger, http://www.ffhtechnical.org/publications/summary/loansize0302.html.

Garikipati, S. (2008), "The impact of lending to women on household vulnerability and women empowerment," World Development, 36, 12, 2620-2642

Ghosh S. and E. Van Tassel (2008), "A Model of microfinance and mission drift," Department of Economics, Florida Atlantic University, December.

Guérin, I. M. Roesch, Venkatasubramanina, M. Sangare, and S. Kuma (2009), "Microfinance and the dynamics of financial vulnerability. Lessons from rural South India," RuMe Working Paper.

Hall, R.E. (1988), "Intertemporal substitution in consumption," Journal of Political Economy, 96, 2, 339-357.

Helms, B. (2006), Access for all, Building Inclusive Financial Systems, CGAP, Washington DC.

Hendricks, L. (2003), "Designing microfinance from an exit-strategy perspective”, Journal of Microfinance, 78, 5, 1,77-88.

Hermes, N. and R. Lensink, (2007), "The empirics of microfinance: What do we know?," Economic Journal, 117, F1-F10.

Hudon, M. (2010), "Subsidies and financial performances of the microfinance institutions: Does management matter?," Journal of International Development, 22,7, 890-905.

Hudon, M. and D. Traca, (forthcoming), "On the efficiency effects of subsidies in microfinance: An empirical inquiry," World Development. 
Kimball, M.S. (1990), "Precautionary saving in the small and in the large", Econometrica, $58,1,53-73$.

McIntosh C. and B. Wydick (2005), "Competition and microfinance", Journal of Development Economics, 78, 271-298.

Mersland R. (2009) "The cost of ownership in microfinance organizations", World Development, 37, 469-478.

Mersland R. and T. Strøm (2010), "Microfinance mission drift?," World Development, 38, $1,28-36$.

MicroBanking Bulletin (2008): MFI benchmark data published by Microfinance Information Exchange, online available at: http://www.themix.org/publications/microbanking-bulletin/2008/08/mfi-benchmark-datamicrobanking-bulletin-august-2008-issu

Morduch, J., (1999a), "The microfinance promise," Journal of Economic Literature, 37, $1569-1614$.

Morduch, J. (1999b), "The role of subsidies in microfinance: Evidence from the Grameen Bank," Journal of Development Economics, 60, 229-248.

Morduch, J. (2005), "Smart subsidy for sustainable microfinance", Finance for the Poor, 6, $4,1-13$.

Nawaz, A. (2010), "Efficiency and productivity of microfinance: Incorporating the role of subsidies," Working Papers CEB 10-009.

Reille, X. and J. Glisovic-Mezieres (2009), Microfinance Funds Continue to Grow Despite the Crisis, CGAP, Washington DC.

Schechtman, J. (1976), “An income fluctuation problem,” Journal of Economic Theory, 12, 218-241.

Zeldes, S.P. (1989), "Optimal consumption with stochastic income: Deviations from certainty equivalence," Quarterly Journal of Economics, 104, 2, 275-298.

Zeller, M. and R. Meyer (2002), The triangle of microfinance: Financial sustainability, outreach and impact, Baltimore: Johns Hopkins University Press.

Zellner, A. (1962), "An efficient method of estimating seemingly unrelated regressions and testing for aggregation bias," Journal of the American Statistical Association, 57, 348-368. 
Zellner, A. (1963), "Estimators for seemingly unrelated regression equations: Some exact finite sample results", Journal of the American Statistical Association, 58, 997-992.

Zellner, A. and D.S. Huang (1963), "Further properties of efficient estimators for seemingly unrelated regression equations," International Economic Review, 3, 300-313. 


\section{Appendix 1: Analytical Solution to Problem (8)}

Consider problem (8) under the joint assumptions that the utility function is exponential with an absolute degree of prudence of $\eta>0$ :

$V(C)=-\frac{1}{\eta} \exp (-\eta C)$

and the subsidy follows a random walk with i.i.d normal innovations:

$K_{t}=K_{t-1}+\xi_{t}, \quad \xi \square N\left(0, \sigma_{\xi}^{2}\right)$,

In that case, under the assumption that $\beta(1+r)=1$, the outreach follows the evolution given by:

$E_{t} N_{1}(t+1)=N_{1}(t)+\frac{\eta \sigma_{\xi}^{2}}{2 \gamma_{1}}$

Equation (A3) shows that the expected outreach grows with the variance of the noise $\sigma_{\xi}^{2}$ that affects the subsidies. This result is robust in wider contexts provided that the absolute degree of prudence of the utility function, $-\frac{V^{\prime \prime}(C)}{V^{\prime \prime}(C)}$, is positive (Kimball, 1990).

However, some usual utility functions, like the quadratic function for which $V^{\prime \prime \prime}(C)=0$, do not fulfill this requirement. When $V(C)=\frac{C^{2}}{2}$, equation (11) becomes:

$E_{t} C_{t+1}=\frac{1}{\beta(1+r)} C_{t}$

As $C_{t}=\gamma_{1} N_{1}(t)$, the dynamics of outreach $N_{1}(t)$ is given by:

$$
E_{t} N_{1}(t+1)=\frac{1}{\beta(1+r)} N_{1}(t)
$$


In order to solve the rational expectation model (A5), let us denote by $\varepsilon_{t+1}$ the rational prediction error on $N_{1}(t+1)$ :

$\varepsilon_{t+1}=E_{t} N_{1}(t+1)-N_{1}(t+1)$

Replacing in (A5) and lagging by one period yields:

$N_{1}(t)=\frac{1}{\beta(1+r)} N_{1}(t-1)+\varepsilon_{t}$

The stochastic process $\left(\varepsilon_{t}\right)$ is the martingale difference (see Broze et al., 1985):

$E_{t}\left[\varepsilon_{t+1}\right]=0$

Equation (A5) exhibits the autoregressive structure of optimal outreach of which dynamics depends on the position of $\frac{1}{\beta(1+r)}$ with respect to unity. In particular, when $\beta(1+r)=1$, the outreach is a random walk. Its stochastic increment is a martingale sequence to be seen as an unpredictable noise with a possibly variable variance, depending notably on the uncertainty on future subsidies. Indeed, the information set $I_{t}$ to which $\varepsilon_{t+1}$ is orthogonal is primarily including the past and current subsidies: $K_{t-i}(i \geq 0) \in I_{t}$. Equation (A7) also shows that uncertainty on future subsidies has a destabilizing impact through the error term $\left(\varepsilon_{t}\right)$, but no systematic impact. 


\section{Appendix 2: Sample Composition}

We list the number of MFIs as well as different MFI-types in each country of the sample.

\begin{tabular}{|c|c|c|c|c|c|}
\hline Country & \# MFIs & \# NGOs & \# NBFIs & \# соор & \# for-profit \\
\hline Albania & 3 & 1 & 0 & 1 & 1 \\
\hline Armenia & 2 & 0 & 2 & 0 & 0 \\
\hline Azerbaijan & 6 & 0 & 6 & 0 & 0 \\
\hline Benin & 7 & 5 & 1 & 1 & 0 \\
\hline Bolivia & 9 & 8 & 1 & 0 & 0 \\
\hline Bosnia and Herzegovina & 14 & 1 & 12 & 0 & 1 \\
\hline Brasil & 12 & 10 & 0 & 1 & 1 \\
\hline Bulgaria & 1 & 0 & 0 & 1 & 0 \\
\hline Burkina Faso & 3 & 1 & 0 & 2 & 0 \\
\hline Burundi & 1 & 0 & 0 & 1 & 0 \\
\hline Cambodia & 5 & 0 & 4 & 0 & 1 \\
\hline Cameroon & 2 & 0 & 1 & 1 & 0 \\
\hline Chad & 1 & 0 & 0 & 1 & 0 \\
\hline Chile & 3 & 0 & 0 & 1 & 2 \\
\hline Colombia & 1 & 1 & 0 & 0 & 0 \\
\hline Croatia & 1 & 0 & 0 & 1 & 0 \\
\hline Democratic Republic of Congo & 1 & 0 & 0 & 1 & 0 \\
\hline Dominican Republic & 1 & 1 & 0 & 0 & 0 \\
\hline Ecuador & 17 & 8 & 0 & 8 & 1 \\
\hline Egypt & 5 & 5 & 0 & 0 & 0 \\
\hline El Salvador & 3 & 3 & 0 & 0 & 0 \\
\hline Ethiopia & 7 & 2 & 4 & 1 & 0 \\
\hline Gambia & 2 & 1 & 1 & 0 & 0 \\
\hline Georgia & 3 & 0 & 3 & 0 & 0 \\
\hline Ghana & 4 & 4 & 0 & 0 & 0 \\
\hline Guatemala & 5 & 5 & 0 & 0 & 0 \\
\hline Guinee & 1 & 0 & 0 & 0 & 1 \\
\hline Haiti & 2 & 2 & 0 & 0 & 0 \\
\hline Honduras & 7 & 5 & 0 & 2 & 0 \\
\hline Jordan & 3 & 2 & 0 & 0 & 1 \\
\hline Kenya & 4 & 3 & 1 & 0 & 0 \\
\hline Khazakhstan & 3 & 0 & 3 & 0 & 0 \\
\hline Kosovo & 5 & 3 & 2 & 0 & 0 \\
\hline Kyrgyz Republic & 3 & 1 & 0 & 1 & 1 \\
\hline Madagascar & 2 & 0 & 0 & 1 & 1 \\
\hline Malawi & 1 & 1 & 0 & 0 & 0 \\
\hline Mali & 1 & 0 & 0 & 1 & 0 \\
\hline Mexico & 8 & 5 & 2 & 0 & 1 \\
\hline Moldova & 2 & 0 & 2 & 0 & 0 \\
\hline Mongolia & 1 & 0 & 0 & 0 & 1 \\
\hline Montenegro & 1 & 0 & 1 & 0 & 0 \\
\hline Morocco & 6 & 6 & 0 & 0 & 0 \\
\hline Mozambique & 1 & 0 & 0 & 0 & 1 \\
\hline Nicaragua & 7 & 7 & 0 & 0 & 0 \\
\hline Niger & 1 & 0 & 0 & 1 & 0 \\
\hline Nigeria & 1 & 0 & 0 & 0 & 1 \\
\hline Peru & 14 & 10 & 1 & 3 & 0 \\
\hline
\end{tabular}




\begin{tabular}{llllll} 
Phillipines & 2 & 2 & 0 & 0 & 0 \\
Romania & 1 & 0 & 1 & 0 & 0 \\
Russia & 12 & 5 & 0 & 7 & 0 \\
Rwanda & 2 & 0 & 1 & 1 & 0 \\
Senegal & 6 & 0 & 0 & 6 & 0 \\
Serbia and Montenegro & 1 & 1 & 0 & 0 & 0 \\
South Africa & 1 & 0 & 0 & 0 & 1 \\
Tajikistan & 4 & 1 & 3 & 0 & 0 \\
Tanzania & 1 & 0 & 0 & 0 & 1 \\
Togo & 3 & 1 & 0 & 2 & 0 \\
Tunisie & 1 & 1 & 0 & 0 & 0 \\
Uganda & 2 & 2 & 0 & 0 & 0 \\
Zambia & 1 & 0 & 1 & 0 & 0 \\
\hline Total & $\mathbf{2 3 0}$ & $\mathbf{1 1 4}$ & $\mathbf{5 3}$ & $\mathbf{4 6}$ & $\mathbf{1 7}$ \\
\hline
\end{tabular}




\section{List of Tables}

\section{Table 1. Summary statistics}

This table reports the mean, median, standard deviation, minimum, and maximum for a number of key-variables.

\begin{tabular}{|c|c|c|c|c|c|c|c|}
\hline variable & definition & $\mathrm{n}$ & mean & median & st. dev. & $\min$. & $\max$. \\
\hline$T L P$ & total outstanding loan portfolio in thousands USD & 676 & 3991 & 1754 & 6153 & 8.47 & 51700 \\
\hline age & number of years in operation & 674 & 8.87 & 7.00 & 6.94 & 0.00 & 42.00 \\
\hline borrowers & number of active borrowers & 665 & 10232 & 4772 & 17282 & 74 & 160209 \\
\hline staff & number of staff members & 673 & 77 & 44 & 99 & 2 & 820 \\
\hline equity & total equity in thousands USD & 676 & 2812 & 1032 & 1130 & 0 & 224000 \\
\hline donated equity & total donated equity in thousands USD & 676 & 2140 & 459 & 1220 & 0 & 259000 \\
\hline donated equity / eq. & donated equity as a percentage of total equity & 676 & 0.71 & 0.53 & 0.94 & 0.00 & 6.08 \\
\hline$S D$ (donated equity /eq) & standard deviation of donated equity & 676 & 0.19 & 0.07 & 0.44 & 0 & 3.51 \\
\hline change in borrowers & Percentage change in active borrowers & 435 & 0.18 & 0.19 & 0.18 & -0.81 & 0.90 \\
\hline avgloan & average loan in USD defined as total loan portfolio divided by borrowers & 658 & 842 & 398 & 1587 & 10.17 & 22307 \\
\hline avgloan / GNIcap & avgloan scaled by per capital GNI & 657 & 0.28 & 0.13 & 0.54 & 0.00 & 6.13 \\
\hline interest rate & interest rates on loans divided by total loan portfolio & 676 & 0.31 & 0.27 & 0.15 & 0.00 & 0.67 \\
\hline ROA & return on assets & 662 & 0.02 & 0.01 & 0.11 & -0.86 & 0.67 \\
\hline$A R O A$ & subsidy-adjusted return on assets & 530 & -0.04 & -0.01 & 0.13 & -1.18 & 0.22 \\
\hline OSS & operational self-sufficiency & 525 & 1.17 & 1.14 & 0.35 & 0.09 & 2.61 \\
\hline FSS & financial self-sufficiency & 562 & 0.96 & 0.97 & 0.30 & 0.12 & 2.22 \\
\hline
\end{tabular}




\section{Table 2. Subsidy uncertainty and changes in clients}

We regress the percentage of change in active borrowers on subsidy uncertainty and controls using OLS and RE. In the different columns we experiment with the inclusion of time and regional dummies. Standard errors are corrected for heteroskedasticity and autocorrelation. In addition, standard errors are clustered per MFI for RE. *,** and $* * *$ denote statistical significance at $10 \%, 5 \%$ and $1 \%$ level, respectively.

\begin{tabular}{lllllll}
\hline Dep. var. change in active borrowers & $(1)$ & $(2)$ & $(3)$ & $(4)$ & $(5)$ & $(6)$ \\
\hline subsidy uncertainty & & & & & & \\
SD(donated equity / equity) & -0.098 & -0.097 & -0.094 & -0.098 & -0.097 & -0.094 \\
& $(0.048)^{* *}$ & $(0.046)^{* *}$ & $(0.043)^{* *}$ & $(0.048)^{* *}$ & $(0.047)^{* *}$ & $(0.044)^{* *}$ \\
controls & & & & & & \\
dumNONPROFIT & -0.034 & -0.036 & -0.003 & -0.035 & -0.037 & -0.003 \\
& $(0.032)^{*}$ & $(0.033)^{*}$ & $(0.037)$ & $(0.032)^{*}$ & $(0.032)^{*}$ & $(0.037)$ \\
dumSAVINGS & -0.044 & -0.039 & -0.001 & -0.045 & -0.040 & -0.002 \\
& $(0.037)^{*}$ & $(0.041)$ & $(0.046)$ & $(0.037)^{*}$ & $(0.041)^{*}$ & $(0.046)$ \\
age & -0.003 & -0.003 & -0.002 & -0.003 & -0.003 & -0.002 \\
& $(0.002)$ & $(0.002)^{*}$ & $(0.002)^{*}$ & $(0.002)^{* *}$ & $(0.002)^{* * *}$ & $(0.002)^{*}$ \\
& & & & & & \\
method & OLS & OLS & OLS & RE & RE & RE \\
regional dummies & excluded & excluded & included & excluded & excluded & included \\
time dummies & excluded & included & included & excluded & included & included \\
\hline $\mathrm{n}$ & 433 & 433 & 432 & 433 & 433 & 432 \\
F-stat / Wald $\chi^{2}$ & $5.83^{* * *}$ & $5.48^{* * *}$ & $5.54^{* * *}$ & $21.49^{* * *}$ & $27.48^{* * *}$ & $66.88^{* * *}$ \\
$\mathrm{R}^{2}$ & 0.05 & 0.06 & 0.09 & 0.09 & 0.09 & 0.11 \\
\hline
\end{tabular}




\section{Table 3. Subsidy uncertainty and positive vs. negative changes in the number of clients}

We present LOGIT and PROBIT-regressions where the dependent is a dummy that is 1 if the percentage of changes in borrowers is positive and 0 if the percentage of changes in borrowers is negative. Standard errors are corrected for heteroskedasticity and autocorrelation. ***, and *** denote statistical significance at $10 \%$, $5 \%$, and $1 \%$ level, respectively.

\begin{tabular}{lllllll}
\hline Dep. var. Dum change positive (0/1) & $(1)$ & $(2)$ & $(3)$ & $(4)$ & $(5)$ & $(6)$ \\
\hline subsidy uncertainty & & & & & & \\
SD(donated equity / equity) & -0.327 & -0.194 & -0.325 & -0.189 & -0.255 & -0.145 \\
& $(0.238)^{*}$ & $(0.136)^{*}$ & $(0.241)^{*}$ & $(0.149)^{* *}$ & $(0.233)^{* *}$ & $(0.141)^{* *}$ \\
controls & & & & & & \\
dumNONPROFIT & -0.318 & -0.178 & -0.352 & -0.206 & -0.109 & -0.063 \\
& $(0.304)^{*}$ & $(0.168)^{*}$ & $(0.297)^{*}$ & $(0.156)^{* *}$ & $(0.341)$ & $(0.193)$ \\
dumSAVINGS & -0.666 & -0.372 & -0.602 & -0.344 & -0.029 & -0.007 \\
& $(0.319)^{* *}$ & $(0.176)^{* *}$ & $(0.342)^{* *}$ & $(0.173)^{* *}$ & $(0.366)$ & $(0.201)$ \\
age & -0.007 & -0.005 & -0.007 & -0.005 & -0.007 & -0.003 \\
& $(0.018)$ & $(0.016)$ & $(0.019)$ & $(0.009)$ & $(0.019)$ & $(0.011)$ \\
& & & & & & \\
method & LOGIT & PROBIT & LOGIT & PROBIT & LOGIT & PROBIT \\
regional dummies & excluded & excluded & excluded & excluded & included & included \\
time dummies & excluded & excluded & included & included & included & included \\
\hline $\mathrm{n}$ & 433 & 433 & 431 & 431 & 416 & 416 \\
Wald $\chi^{2}$ & $8.82^{* * *}$ & $8.81^{* * *}$ & $16.98^{* * *}$ & $15.39^{* * *}$ & $35.13^{* * *}$ & $35.39^{* * *}$ \\
pseudo $R^{2}$ & 0.03 & 0.03 & 0.07 & 0.09 & 0.09 & 0.11 \\
\hline
\end{tabular}




\section{Table 4. System of equations: interest rate and loan size}

We jointly regress loan size and the interest rate on the standard deviation of donated equity/equity and a set of controls in a system of equations also called simultaneous equation modeling. The estimation method is the seemingly unrelated regressions-procedure (SUR) developed in Zellner (1962); Zellner and Huang (1962) and Zellner (1963). This estimation procedure takes into account the correlations between the errors of the respective regression models by means of estimating a joint covariance matrix. The Breusch-Pagan test asserts the null-hypothesis that the residuals of the separate regressions are uncorrelated. We also report a joint F-test for subsidy uncertainty that asserts the null-hypothesis that the coefficients for $\mathrm{SD}$ (donated equity/equity) are jointly significant. $* * *$, and $* * *$ denote statistical significance at $10 \%, 5 \%$, and $1 \%$ level, respectively.

\begin{tabular}{|c|c|c|c|c|c|c|}
\hline $\begin{array}{l}\text { Simultaneous equation modeling } \\
\text { Dependent variable }\end{array}$ & $\begin{array}{l}1) \\
\text { Interest rate }\end{array}$ & Loan size & $\begin{array}{l}\text { (2) } \\
\text { Interest rate }\end{array}$ & Loan size & $\begin{array}{l}3) \\
\text { Interest rate }\end{array}$ & Loan size \\
\hline $\begin{array}{l}\text { subsidy uncertainty } \\
\text { SD(donated equity/equity) } \\
\text { controls }\end{array}$ & $\begin{array}{l}0.300 \\
(0.087)^{\star * *}\end{array}$ & $\begin{array}{l}0.035 \\
(0.083)\end{array}$ & $\begin{array}{l}0.309 \\
(0.086)^{\star * *}\end{array}$ & $\begin{array}{l}0.023 \\
(0.083)\end{array}$ & $\begin{array}{l}0.303 \\
(0.086)^{\star * *}\end{array}$ & $\begin{array}{l}0.061 \\
(0.083)\end{array}$ \\
\hline Inequity & $\begin{array}{l}-0.049 \\
(0.017)^{* * *}\end{array}$ & $\begin{array}{l}0.038 \\
(0.016)^{* *}\end{array}$ & $\begin{array}{l}-0.045 \\
(0.017)^{\star * *}\end{array}$ & $\begin{array}{l}0.034 \\
(0.016)^{* *}\end{array}$ & $\begin{array}{l}-0.044 \\
(0.017)^{\star * *}\end{array}$ & $\begin{array}{l}0.025 \\
(0.017)^{*}\end{array}$ \\
\hline age & $\begin{array}{l}-0.001 \\
(0.004)\end{array}$ & $\begin{array}{l}0.002 \\
(0.004)\end{array}$ & $\begin{array}{l}-0.002 \\
(0.004)\end{array}$ & $\begin{array}{l}0.002 \\
(0.004)\end{array}$ & $\begin{array}{l}-0.001 \\
(0.004)\end{array}$ & $\begin{array}{l}0.004 \\
(0.004)\end{array}$ \\
\hline dumNONPROFIT & $\begin{array}{l}0.005 \\
(0.050)\end{array}$ & $\begin{array}{l}-0.091 \\
(0.048)^{*}\end{array}$ & $\begin{array}{l}0.013 \\
(0.050)\end{array}$ & $\begin{array}{l}-0.085 \\
(0.048)^{*}\end{array}$ & $\begin{array}{l}-0.024 \\
(0.056)\end{array}$ & $\begin{array}{l}-0.036 \\
(0.054)\end{array}$ \\
\hline dumSAVING & $\begin{array}{l}0.010 \\
(0.054)\end{array}$ & $\begin{array}{l}0.083 \\
(0.052)^{*}\end{array}$ & $\begin{array}{l}-0.021 \\
(0.055)\end{array}$ & $\begin{array}{l}0.074 \\
(0.053)^{*}\end{array}$ & $\begin{array}{l}0.021 \\
(0.062)\end{array}$ & $\begin{array}{l}0.036 \\
(0.060)\end{array}$ \\
\hline $\begin{array}{l}\text { PAR } \\
\text { donated equity/equity }\end{array}$ & $\begin{array}{l}-0.002 \\
(0.004) \\
0.016 \\
(0.035)\end{array}$ & $\begin{array}{l}0.005 \\
(0.004) \\
-0.062 \\
(0.034)^{*}\end{array}$ & $\begin{array}{l}-0.002 \\
(0.004) \\
0.005 \\
(0.035)\end{array}$ & $\begin{array}{l}0.004 \\
(0.004) \\
-0.064 \\
(0.034)^{*}\end{array}$ & $\begin{array}{l}-0.001 \\
(0.004) \\
0.018 \\
(0.036)\end{array}$ & $\begin{array}{l}0.005 \\
(0.004)^{*} \\
-0.098 \\
(0.035)^{\star * *}\end{array}$ \\
\hline $\begin{array}{l}\text { method } \\
\text { regional dummies } \\
\text { time dummies }\end{array}$ & $\begin{array}{l}\text { SUR } \\
\text { excluded } \\
\text { excluded }\end{array}$ & & $\begin{array}{l}\text { SUR } \\
\text { excluded } \\
\text { included }\end{array}$ & & $\begin{array}{l}\text { SUR } \\
\text { included } \\
\text { included }\end{array}$ & \\
\hline $\begin{array}{l}\text { model stats } \\
n \\
\text { Breusch-Pagan for independence } \\
\text { joint F-test for subsidy uncertainty }\end{array}$ & $\begin{array}{l}573 \\
3.409^{* *} \\
6.18^{* * *}\end{array}$ & & $\begin{array}{l}573 \\
4.960^{\star *} \\
6.61^{\star * *}\end{array}$ & & $\begin{array}{l}572 \\
3.053^{* *} \\
6.66^{* * *}\end{array}$ & \\
\hline
\end{tabular}




\section{Table 5. Robustness checks}

We test the robustness of the results by re-running the joint regressions of loan size and the interest rate on subsidy uncertainty and a number of controls using SUR with a number of modifications. In Panel A we use the spread of donated equity scaled by total equity instead of the standard deviation as a measure for subsidy uncertainty. In Panel B only those MFIs for which we have 3 years of observation (53.3\% of the sample) are being used. In Panel $\mathrm{C}$ we adjust subsidies for donations in cash, in-kind subsidies and revenues from subsidies. The Breusch-Pagan test asserts the null-hypothesis that the residuals of the separate regressions are uncorrelated. We also report a joint F-test for subsidy uncertainty that asserts the null-hypothesis that the coefficients for $\mathrm{SD}$ (donated equity/equity) are jointly significant. $* * *$, and $* * *$ denote statistical significance at $10 \%, 5 \%$, and $1 \%$ level, respectively.

\section{Panel A. Spread of subsidies instead of standard deviation}

\begin{tabular}{|c|c|c|c|c|c|c|}
\hline $\begin{array}{l}\text { Simultaneous equation modeling } \\
\text { Dependent variable }\end{array}$ & $\begin{array}{l}\text { (1) } \\
\text { Interest rate }\end{array}$ & Loan size & $\begin{array}{l}\text { (2) } \\
\text { Interest rate }\end{array}$ & Loan size & $\begin{array}{l}\text { (3) } \\
\text { Interest rate }\end{array}$ & Loan size \\
\hline $\begin{array}{l}\text { subsidy uncertainty } \\
\text { Spread(donated equity/equity) } \\
\text { controls }\end{array}$ & $\begin{array}{l}0.287 \\
(0.045)^{* * *}\end{array}$ & $\begin{array}{l}0.013 \\
(0.044)\end{array}$ & $\begin{array}{l}0.289 \\
(0.045)^{* * *}\end{array}$ & $\begin{array}{l}0.006 \\
(0.045)\end{array}$ & $\begin{array}{l}0.284 \\
(0.045)^{\star * *}\end{array}$ & $\begin{array}{l}0.027 \\
(0.045)\end{array}$ \\
\hline Inequity & $\begin{array}{l}-0.035 \\
(0.016)^{* *}\end{array}$ & $\begin{array}{l}0.037 \\
(0.016)^{* *}\end{array}$ & $\begin{array}{l}-0.031 \\
(0.016)^{* *}\end{array}$ & $\begin{array}{l}0.034 \\
(0.016)^{* *}\end{array}$ & $\begin{array}{l}-0.032 \\
(0.017)^{\star *}\end{array}$ & $\begin{array}{l}0.025 \\
(0.017)\end{array}$ \\
\hline age & $\begin{array}{l}-0.002 \\
(0.004)\end{array}$ & $\begin{array}{l}0.002 \\
(0.004)\end{array}$ & $\begin{array}{l}-0.003 \\
(0.004)\end{array}$ & $\begin{array}{l}0.002 \\
(0.004)\end{array}$ & $\begin{array}{l}-0.002 \\
(0.004)\end{array}$ & $\begin{array}{l}0.004 \\
(0.004)\end{array}$ \\
\hline dumNONPROFIT & $\begin{array}{l}0.003 \\
(0.049)\end{array}$ & $\begin{array}{l}-0.090 \\
(0.048)^{* *}\end{array}$ & $\begin{array}{l}0.011 \\
(0.048)\end{array}$ & $\begin{array}{l}-0.086 \\
(0.048)^{*}\end{array}$ & $\begin{array}{l}-0.023 \\
(0.045)\end{array}$ & $\begin{array}{l}-0.036 \\
(0.054)\end{array}$ \\
\hline dumSAVING & $\begin{array}{l}-0.004 \\
(0.053)\end{array}$ & $\begin{array}{l}0.083 \\
(0.052)^{* *}\end{array}$ & $\begin{array}{l}-0.035 \\
(0.053)\end{array}$ & $\begin{array}{l}0.074 \\
(0.053)^{*}\end{array}$ & $\begin{array}{l}0.001 \\
(0.061)\end{array}$ & $\begin{array}{l}0.036 \\
(0.060)\end{array}$ \\
\hline PAR & $\begin{array}{l}-0.001 \\
(0.002)\end{array}$ & $\begin{array}{l}0.005 \\
(0.004)\end{array}$ & $\begin{array}{l}-0.001 \\
(0.004)\end{array}$ & $\begin{array}{l}0.004 \\
(0.004)\end{array}$ & $\begin{array}{l}-0.001 \\
(0.003)\end{array}$ & $\begin{array}{l}0.005 \\
(0.004)\end{array}$ \\
\hline donated equity/equity & $\begin{array}{l}-0.051 \\
(0.035)\end{array}$ & $\begin{array}{l}-0.059 \\
(0.034)^{* *}\end{array}$ & $\begin{array}{l}-0.061 \\
(0.035)^{*}\end{array}$ & $\begin{array}{l}-0.061 \\
(0.035)^{\star *}\end{array}$ & $\begin{array}{l}-0.048 \\
(0.036)^{\star *}\end{array}$ & $\begin{array}{l}-0.095 \\
(0.035)^{\star * *}\end{array}$ \\
\hline $\begin{array}{l}\text { method } \\
\text { regional dummies } \\
\text { time dummies }\end{array}$ & $\begin{array}{l}\text { SUR } \\
\text { excluded } \\
\text { excluded }\end{array}$ & & $\begin{array}{l}\text { SUR } \\
\text { excluded } \\
\text { included }\end{array}$ & & $\begin{array}{l}\text { SUR } \\
\text { included } \\
\text { included }\end{array}$ & \\
\hline $\begin{array}{l}\text { model stats } \\
n \\
\text { Breusch-Pagan for independence } \\
\text { joint F-test for subsidy uncertainty }\end{array}$ & $\begin{array}{l}573 \\
3.63^{* *} \\
19.97^{* * *}\end{array}$ & & $\begin{array}{l}573 \\
5.16^{\star *} \\
20.67^{\star * *}\end{array}$ & & $\begin{array}{l}572 \\
3.73^{* *} \\
20.22^{* * *}\end{array}$ & \\
\hline
\end{tabular}


Panel B. Only MFIs for which we have observations for 3 years

\begin{tabular}{|c|c|c|c|c|c|c|}
\hline Simultaneous equation modeling & (1) & & (2) & & (3) & \\
\hline Dependent variable & Interest rate & Loan size & Interest rate & Loan size & Interest rate & Loan size \\
\hline subsidy uncertainty & & & & & & \\
\hline $\mathrm{SD}$ (donated equity/equity) & $\begin{array}{l}0.071 \\
(0.029)^{\star \star *}\end{array}$ & $\begin{array}{l}0.070 \\
(0.081)\end{array}$ & $\begin{array}{l}0.071 \\
(0.029)^{\star \star \star}\end{array}$ & $\begin{array}{l}0.079 \\
(0.081)\end{array}$ & $\begin{array}{l}0.060 \\
(0.029)^{\star *}\end{array}$ & $\begin{array}{l}0.073 \\
(0.082)\end{array}$ \\
\hline controls & & & & & & \\
\hline Inequity & $\begin{array}{l}-0.021 \\
(0.006)^{\star \star *}\end{array}$ & $\begin{array}{l}0.025 \\
(0.017)^{\star *}\end{array}$ & $\begin{array}{l}-0.021 \\
(0.007)^{\star \star \star}\end{array}$ & $\begin{array}{l}0.024 \\
(0.018)^{\star}\end{array}$ & $\begin{array}{l}-0.016 \\
(0.007)^{\star *}\end{array}$ & $\begin{array}{l}0.026 \\
(0.019)\end{array}$ \\
\hline age & 0.001 & -0.002 & 0.001 & -0.002 & -0.001 & -0.002 \\
\hline & $(0.001)$ & $(0.004)$ & $(0.001)$ & $(0.004)$ & $(0.001)$ & $(0.005)$ \\
\hline dumNONPROFIT & 0.057 & -0.139 & 0.053 & -0.141 & 0.006 & -0.156 \\
\hline & $(0.020)^{* * *}$ & $(0.055)^{\star *}$ & $(0.020)^{\star * \star}$ & $(0.056)^{\star *}$ & $(0.024)$ & $(0.069)^{* \star *}$ \\
\hline dumSAVING & -0.076 & 0.187 & -0.076 & 0.157 & -0.096 & 0.089 \\
\hline & $(0.023)^{\star \star \star}$ & $(0.062)^{* * *}$ & $(0.023)^{\star * *}$ & $(0.064)^{* \star \star}$ & $(0.025)^{\star \star \star}$ & $(0.072)$ \\
\hline PAR & 0.003 & 0.004 & 0.004 & 0.002 & 0.003 & 0.002 \\
\hline & $(0.001)$ & $(0.004)$ & $(0.002)^{\star *}$ & $(0.004)$ & $(0.002)^{\star *}$ & $(0.004)$ \\
\hline donated equity/equity & -0.038 & -0.001 & -0.040 & -0.003 & -0.032 & -0.011 \\
\hline & $(0.013)$ & $(0.037)$ & $(0.013)$ & $(0.038)$ & $(0.014)^{\star *}$ & $(0.039)$ \\
\hline method & SUR & & SUR & & SUR & \\
\hline regional dummies & excluded & & excluded & & included & \\
\hline time dummies & excluded & & included & & included & \\
\hline model stats & & & & & & \\
\hline n & 312 & & 312 & & 312 & \\
\hline Breusch-Pagan for independence & $10.76^{* \star *}$ & & $9.77^{* * *}$ & & $10.938^{* \star *}$ & \\
\hline joint F-test for subsidy uncertainty & $6.96^{\star \star \star}$ & & $4.54^{\star *}$ & & $3.98^{\star *}$ & \\
\hline
\end{tabular}


Panel C. Subsidies adjusted for cash-donations, in-kind subsidies and revenues from subsidies

\begin{tabular}{|l|ll|ll|ll|}
\hline $\begin{array}{l}\text { Simultaneous equation modeling } \\
\text { Dependent variable }\end{array}$ & $\begin{array}{l}(1) \\
\text { Interest rate }\end{array}$ & Loan size & $\begin{array}{l}(2) \\
\text { Interest rate }\end{array}$ & Loan size & $\begin{array}{l}(3) \\
\text { Interest rate }\end{array}$ & Loan size \\
\hline subsidy uncertainty & & & & & & \\
SD(donated equity/equity) & 0.322 & 0.002 & 0.340 & 0.009 & 0.322 & 0.032 \\
& $(0.079)^{* * *}$ & $(0.075)$ & $(0.078)^{* * *}$ & $(0.076)$ & $(0.078)^{* * *}$ & $(0.076)$ \\
controls & & & & & \\
Inequity & -0.045 & 0.035 & -0.040 & 0.031 & -0.040 & 0.022 \\
& $(0.017)^{* * *}$ & $(0.016)^{* *}$ & $(0.017)^{* *}$ & $(0.016)^{*}$ & $(0.017)^{* *}$ & $(0.017)^{*}$ \\
age & -0.001 & 0.002 & -0.002 & 0.002 & -0.001 & 0.004 \\
& $(0.004)$ & $(0.004)$ & $(0.004)$ & $(0.004)$ & $(0.004)$ & $(0.004)$ \\
dumNONPROFIT & 0.007 & -0.088 & 0.014 & -0.084 & -0.022 & -0.032 \\
dumSAVING & $(0.050)$ & $(0.048)^{* *}$ & $(0.049)$ & $(0.048)^{* *}$ & $(0.056)$ & $(0.052)$ \\
PAR & 0.014 & 0.083 & -0.016 & 0.074 & 0.023 & 0.034 \\
& $(0.054)$ & $(0.052)^{*}$ & $(0.054)$ & $(0.053)^{*}$ & $(0.061)$ & $(0.060)$ \\
donated equity/equity & -0.001 & 0.005 & -0.002 & 0.004 & -0.001 & 0.004 \\
& $(0.004)$ & $(0.004)$ & $(0.004)$ & $(0.004)$ & $(0.001)$ & $(0.004)$ \\
method & 0.006 & -0.051 & -0.006 & -0.053 & 0.011 & -0.089 \\
regional dummies & $(0.031)$ & $(0.030)^{* *}$ & $(0.031)$ & $(0.031)^{*}$ & $(0.032)$ & $(0.031)^{* * *}$ \\
time dummies & & & & & &
\end{tabular}

